\title{
1964: golpe ou revolução? A disputa pela memória nas páginas do jornal O Estado de S. Paulo
}

1964: coup or revolution? The contest for the memory pages of the newspaper O Estado de S. Paulo

\author{
Cássio Augusto Samogin Almeida Guilherme*
}

\begin{abstract}
Resumo
O presente texto analisa as edições do jornal $\mathbf{O}$ Estado de $\mathbf{S}$. Paulo publicadas a cada 31 de março e 01 de abril entre os anos da Nova República brasileira (1985-2016). Nosso objetivo é discutir a disputa pela memória do golpe e dos anos de Ditadura no Brasil. Nossa hipótese é que nos primeiros momentos o Estadão legitimou o discurso da "revolução democrática", posteriormente, assumindo a interpretação de uma "contrarrevolução" e por fim, nos governos petistas, há uma acirrada disputa pela memória, em especial, no contexto da Comissão Nacional da Verdade.
\end{abstract}

Palavras-chave: Estadão; Ditadura; Memória.

\begin{abstract}
This article analyzes the newspaper editions $\mathbf{O}$ Estado de S. Paulo published each March 31st and April 01st about the years of the New Brazilian Republic (1985-2016). Our goal is to discuss the dispute about the coup memory and the years of dictatorship in Brazil. Our conjecture is that in the first moments the journal Estadão legitimized the speech of the "democratic revolution", after it the journal assuming the interpretation of a "counterrevolution" and now at the PT governments period there is a strong competition for memory, especially in the context of the Comissão Nacional da Verdade (National Commission of Truth).
\end{abstract}

Keywords: Estadão; Dictatorship; Memory.

\section{Introdução}

Embora já passados mais de cinquenta anos do golpe civil-militar de 1964 que depôs o presidente João Goulart e lançou o país na Ditadura, que durou 21 anos, a disputa pela memória daquele acontecimento permanece aberta e contenciosa. Atualmente, o Brasil observa setores de direita reivindicarem a data de 31 de março como um movimento revolucionário, que evitou tornar o país uma "nova Cuba

\footnotetext{
* Doutorando em História Política pela Universidade Estadual de Maringá (UEM). Mestre em História em Universidade Estadual de Maringá (UEM). Professor da Universidade Federal do Sul e Sudeste do Pará (UNIFESSPA).
} 
comunista", enquanto setores de esquerda sustentam que o $1^{\circ}$ de abril foi um golpe que rasgou a Constituição. Como se vê, as diferenças de interpretação dizem respeito até mesmo à data do fato.

Mais que isso. No Brasil, dividido entre "coxinhas" e "petralhas"1, cresce o número de movimentos e adeptos da interpretação direitista que consideram a historiografia produzida até aqui, como sendo marcada por viés ideológico à esquerda, portanto, não isenta na interpretação dos fatos. Como consequência, vê-se setores do país que, por desinformação ou desonestidade, defendem a volta dos militares. Dizem eles que "na época da Ditadura que era bom", negam a existência da tortura e defendem o absurdo de uma "intervenção militar constitucional”, seja lá o que isso signifique na mente dessas pessoas.

Assim, o objetivo deste texto é contribuir no debate sobre a memória do golpe de 1964, tendo por base o jornal O Estado de S. Paulo (Estadão ou OESP) ${ }^{2}$.Foram tomadas como objeto de análise todas as edições desse periódico, publicadas nos dias 31 de março e 01 de abril entre os anos de 1985 e 2016, e que fazem algum tipo de referência ao aniversário do fato, totalizando 78 páginas $^{3}$. Nosso recorte diz respeito ao período chamado de Nova República brasileira, quando os militares deixaram o Poder Executivo e este voltou a ser ocupado por civis eleitos.

Conforme Juremir Machado da Silva, "o golpe de 1964 foi midiático-civilmilitar. Sem o trabalho da imprensa não haveria legitimidade para a derrubada do presidente João Goulart. Os grandes jornais de cada capital atuaram como incentivadores e árbitros." (SILVA, 2014, p. 32). O jornal O Estado de S. Paulo foi

\footnotetext{
${ }^{1}$ Embora não haja uma única definição aceita popularmente ou mesmo consolidada no meio acadêmico, ambosos termos são comumente utilizados de forma pejorativano linguajar popular para rotular as preferências político-ideológicas do interlocutor com o qual se debate política no Brasil contemporâneo. "Coxinha" pode ser o indivíduo politicamente conservador e de elevada capacidade financeira, mas também, eprincipalmente, o indivíduo que mesmo não pertencendo às classes altas defende a ideologia neoliberal, embora não se aperceba disso e não a compreenda. Comumente vota em partidos de direita. "Petralha" é o indivíduo que defende ou milita em causas progressistas e que é comparado por seus detratores aos ladrões "irmãos Metralhas" do desenho animado. Comumente vota em partidos de esquerda. Os "coxinhas" acusam os "petralhas" de serem coniventes com os escândalos de corrupção dos governos do PT; os "petralhas" acusam os "coxinhas" de serem manipulados por políticos conservadores, neoliberais e também corruptos.

${ }^{2}$ Optamos por alternar as três formas de grafia por dois motivos: o jornal utiliza ambas as formas em suas reportagens; para não cansar o leitor com a repetição de uma única grafia a ser repetida ao longo de todo o texto.

${ }^{3}$ Todo o acervo do jornal O Estado de S. Paulo desde 1875 está digitalizado e disponível para consultas online para assinantes através do site www.acervo.estadao.com.br

${ }^{4} \mathrm{O}$ autor usa o conceito de "midiático-civil-militar" para enfatizar a tese de que o Golpe de 1964 teve imprescindível participação da imprensa no processo de desestabilização do presidente João Goulart, no
} 
conspirador confesso daquele movimento, porém, segundo Maria de Aquino, não da forma que o senso comum estabelece, ou seja, pelo seu conservadorismo paulista, mas sim como defensor do ideal liberal, que na visão do jornal, estava ameaçado pelo “perigo comunista", representado pelo governo de João Goulart (AQUINO, 1999).

$\mathrm{O}$ uso de fontes jornalísticas em pesquisas historiográficas dialoga com as renovações nos estudos em História Política que buscam ampliar as fontes e os métodos de análise. Sabemos que nem sempre a exatidão e a independência dominam os conteúdos dos jornais e seus editoriais, porém é preciso reconhecer que, embora atue na fabricação da opinião pública, a imprensa é "produtora considerável de informações diversas, que esclarecem as atitudes e os comportamentos: ela noticia reuniões políticas, o número de participantes, traz relatos de manifestações” (BECKER, 2003, p. 196-197). Nessa linha de pensamento, escreve a historiadora Tania Regina de Luca (2011), ao defender as pesquisas nos periódicos, que "as renovações no estudo da História Política, por sua vez, não poderiam dispensar a imprensa, que cotidianamente registra cada lance dos embates na arena do poder" (LUCA, 2011, p. 128). Nas palavras do jornalista Carlos Chagas (2014):

É implacável o papel da imprensa na história. Tratando-se da fonte primária dos acontecimentos, registra os fatos sem que seus personagens tenham ainda oportunidade de retocá-los conforme seus interesses, nos livros de memórias, ou na voz de seus simpatizantes, nas biografias (CHAGAS, 2014, p. 270).

Avaliamos que todo "documento é sempre portador de um discurso que, assim considerado, não pode ser visto como algo transparente". Por isso mesmo, devemos atentar para o "modo através do qual se apresenta o conteúdo histórico que pretende examinar, quer se trate de uma simples informação, quer se trate de ideias" (CARDOSO; VAINFAS, 1997, p. 377). Nosso objetivo neste texto é observar o discurso do Estadão sobre o golpe de 1964, a cada aniversário ocorrido ao longo da Nova República brasileira, e se, ao longo dos anos, o jornal alterou o seu discurso conforme o tempo histórico vivido.

Como aponta Carla Silva (2014), atualmente, há certo consenso em admitir a imprensa como fonte primária, desde que esclarecidas a problemática e a temática da investigação, que se faça a crítica ao documento e suas condições de produção, de verificabilidade, "verdade" e lugar diante dos fatos. No mesmo sentido, a historiadora

convencimento da sociedade civil acerca da importância de uma "revolução" e na posterior consolidação do regime ditatorial militar. 
Maria Helena Capelato (2014), em trabalho recente, defendeu o uso de fontes jornalísticas, em especial a grande imprensa, para as pesquisas em História do Tempo Presente.

A grande imprensa define-se como filiada aos ideais liberais e republicanos, que, com base na liberdade de expressão, teria a responsabilidade social de atuar na fiscalização dos poderes como um "quarto poder". Para isso, a imprensa se reivindica como alheia aos conflitos sociais, políticos e econômicos ao trabalhar com imparcialidade na observação e denúncia de irregularidades em nome dos interesses de toda a coletividade.

Entretanto, pesquisas ${ }^{5}$ que têm a imprensa como objeto de análise apontam para as contradições e limites desses ideais propagados pela grande mídia: a atuação como máquinas de produção do consenso do pensamento único às ideias neoliberais e bloqueio de outras formas de pensamento contrária à teoria liberal; a liberdade de expressão é, na verdade, a liberdade do proprietário do veículo de imprensa que define o que publicar; a fiscalização aos poderes é seletiva; como uma empresa privada que visa ao lucro, depende da venda do produto e do patrocínio de anunciantes, a imprensa não está alheia aos conflitos sociais, políticos e econômicos; a alegada imparcialidade em nome dos interesses de toda a coletividade se constitui em disfarce para o caráter ideológico nas narrativas publicadas pela imprensa.

Embora a imprensa possa não ter vínculos com partidos políticos, as pesquisas apontam para a manutenção de vínculos de classe. A grande imprensa brasileira, a partir dos anos 1990, agiu partidariamente na produção de um consenso ideológico neoliberal, enquanto parecia neutra, objetiva e independente aos olhos do leitor ${ }^{6}$. Assim, as mídias de informação atuam em dois campos que se complementam: o econômico, pois se trata de uma empresa que fabrica um produto a ser comercializado e que visa ao lucro; e o simbólico, uma vez que seu produto busca participar da construção da opinião pública (CHARAUDEU, 2013), já que o jornal é sempre um mediador, isto é, o que faz a triagem dos acontecimentos antes de publicá-lo na forma de notícia ou opinião. Em resumo, o jornal tem a dupla função de formar e informar.

Conforme a historiadora Tania de Luca (2011, p. 139), “a imprensa periódica seleciona, ordena, estrutura e narra, de uma determinada forma, aquilo que se elegeu como digno de chegar até o público". No caso dos jornais, seu público leitor é mais

\footnotetext{
${ }^{5}$ Ver Carla Luciana Silva e Edina Rautenberg (2014), História e imprensa: estudos de hegemonia.

${ }^{6}$ Ver Carla Luciana Silva e Edina Rautenberg (2014), História e imprensa: estudos de hegemonia.
} 
elitizado, os chamados formadores de opinião que, a partir da leitura do periódico, atuarão socialmente na propagação da narrativa por eles consumida diariamente (HERNANDES, 2012).

\title{
O Estado de S. Paulo - golpista e censurado
}

O jornalista Carlos Chagas, testemunha daqueles anos, aponta Júlio de Mesquita Filho como um dos artífices do golpe de 1964, "metido até o pescoço na conspiração" (CHAGAS, 2014, p. 43), junto com Roberto Marinho do jornal O Globo. Sobre a atuação do Estadão no movimento, que golpeou a democracia e depôs o presidente João Goulart em 1964, argumenta Maria Aparecida de Aquino (1999) que:

\begin{abstract}
Acompanhando-se os editoriais de OESP no período que antecede imediatamente ao golpe de 1964, observa-se o tom alarmista de crítica ao governo de João Goulart [...] conclamando a sociedade civil e as Forças Armadas na defesa do que consideram como interesses gerais e direitos naturais dos homens e conspirando abertamente contra o governo instituído [...] OESP não somente apóia o golpe, mas encara-o como viva aspiração nacional. (AQUINO, 1999, p. 42 - itálico no original).
\end{abstract}

Segundo essa pesquisadora, a linha editorial liberal e de intervenção política do jornal é "teoricamente justificável nos moldes do liberalismo lockeano", em que o poder do governante "é outorgado pelos membros da sociedade, podendo ser revogado pela insurreição destes, caso as autoridades cometam o abuso do mando" (AQUINO, 1999, p. 39). Assim, no contexto de Guerra Fria, o jornal entendia que as propostas de reformas de base do presidente João Goulart e suas aproximações com setores da esquerda política e sindical representavam abuso de poder e usurpação dos direitos naturais dos indivíduos, o que justificaria a rebelião armada contra o governante.

Ainda quando do comício da Central do Brasil, no qual Jango discursou, o OESP publicou que o povo da Guanabara teria ficado em casa, comparecendo apenas militantes pelegos arregimentados pelo caudilhismo (SILVA, 2014). Concretizado o golpe, o Estadão publica que "Democratas dominam toda a Nação. Ignorado o destino do ex-presidente Goulart"?

Nos primeiros anos do governo de Castelo Branco, o jornal apoiou e, em certos momentos, até pediu a "ampliação da Revolução" para que ocorressem mais cassações de políticos considerados subversivos e corruptos. Exemplo é a pressão do Estadão, o

\footnotetext{
${ }^{7}$ Jornal O Estado de S. Paulo - 03-04-1964 - p. 01.
} 
jornal que mais se empenhou pela cassação dos direitos políticos do ex-presidente Juscelino Kubitschek e a exaltação após a efetivação (CHAGAS, 2014). Nas páginas do livro de memórias do jornalista Carlos Chagas, podemos perceber que Júlio de Mesquita Filho teve participação ativa nas reuniões que tentavam evitar a ruptura de Carlos Lacerda com os governistas militares, ou seja, o proprietário do Estadão não apenas apoiou o golpe como, também, atuou no sentido de manter a estabilidade política do regime em seus anos iniciais.

Os problemas do O Estado de S. Paulo com a Ditadura começam com a apreensão do jornal, dentre outros periódicos, nos dias 13 e 14 de dezembro de 1968, no contexto do Ato Institucional $\mathrm{n}^{\circ} 5$, que "tornou o regime uma indiscutível ditadura, reabriu a temporada de punições e serviu de base para a montagem dos aparatos que constituíram a repressão política" (FICO, 2015, p. 67). O editorial "Instituições em frangalhos" irritou os militares. No texto, o jornal credita a "vitória de 64" a toda coletividade e não apenas às Forças Armadas, que alijaram os civis do governo; os excessos dos militares são qualificados como "a ditadura militar que vivemos desde 1964" e aponta para a desagregação institucional com a edição de mais um Ato Institucional. Para Maria de Aquino, "o abuso do poder pelos chefes da nação, usurpando os direitos naturais dos homens, constitui o fundamento da oposição de OESP; em ambos os casos [contra Jango e contra o AI-5], de base liberal" (AQUINO, 1999, p. 53).

Entre os anos de 1968 e 1972, o Estadão, como os demais jornais do país, atuava no campo da autocensura, ou seja, a própria direção do periódico determinava que certos temas, possivelmente desagradáveis à Ditadura, não deveriam ser publicados e, se publicados, com viés pró-governo. Ao mesmo tempo, os jornais recebiam telefonemas e bilhetinhos vindos do governo federal com os assuntos que não deveriam ser publicados. O jornalista Carlos Chagas, então diretor da sucursal do jornal em Brasília, bajula seus patrões, dizendo que eles "não aceitavam ordens telefônicas de censura, fazia-se necessária a presença do censor, mas a maior parte da imprensa amestrada praticava a autocensura" (CHAGAS, 2015, p. 15).

Poucos foram os jornais que ficaram sob censura prévia ${ }^{8}$ da Ditadura. O OESP foi um deles. Conforme a bibliografia, o ano de 1972 marca a instauração da censura prévia no país. O jornal preparava uma reportagem especial sobre anistia, na qual

\footnotetext{
${ }^{8}$ Ato de só autorizar a publicação do jornal após aprovação do censor militar. Caso uma reportagem não fosse do agrado do censor responsável, a mesma era retirada ou alterada antes do jornal ser publicado.
} 
constariam falas dos ex-presidentes ainda vivos e monitorados pelo Serviço Nacional de Informações (SNI), que tentou convencer a direção do jornal a não publicar a matéria. $\mathrm{O}$ Estadão se negou e no dia 03 de setembro de 1972, o jornal foi ocupado pelos censores. Até janeiro de 1975, foram 1.136 matérias censuradas, no todo ou em parte, sobre questões políticas, sociais, econômicas, educacionais e internacionais, número considerável delas assinadas pelo jornalista Carlos Chagas (AQUINO, 1999).

É popular a estratégia de resistência adotada pelo OESP em publicar receitas de bolos e poesias, em especial Os Lusíadas do poeta português Luís de Camões, para preencher os espaços vazios que seriam deixados pelas matérias censuradas. Para Maria de Aquino, a presença inusitada dos poemas tinha o objetivo de chamar atenção do leitor às páginas antes destinadas ao noticiário político. Assim, a direção do Estadão esperava que o público leitor percebesse que algo estranho estava acontecendo: o jornal estava sob censura da Ditadura.

Em janeiro de 1975, o último censor deixa as dependências do O Estado de S. Paulo, embora os telefonemas e bilhetinhos continuassem chegando à redação do jornal. Entre 1975 e 1978, há um processo de diminuição da censura prévia à imprensa que passa a ser mais discreta e seletiva.

\section{Os aniversários do Golpe no Estadão}

Como se observa na seção anterior o Estadão teve trajetória de atuação partidarizada no golpe civil-militar de 1964. O jornal não se pretendeu à imparcialidade. Assim, se torna importante debater a memória sobre a Ditadura que o OESP publicou no período democrático.

A seguir, apresentaremos a análise de 78 páginas do jornal publicadas nos dias 31 de março e 01 de abril dos anos 1985 a 2016 ${ }^{9}$. Entre editoriais, notícias jornalísticas, publicações das Ordens do Dia $^{10}$ nas Forças Armadas, cadernos especiais de 30 e 40 anos do fato, há importantes entrevistas e artigos de políticos que foram governo e oposição naqueles anos, além de empresários, jornalistas e pesquisadores. Para efeitos meramente didáticos, a análise foi dividida em três períodos.

\footnotetext{
${ }^{9}$ Não faremos uma análise quantitativa e exaustiva de todas as citações e referência, mas sim uma análise qualitativa das citações que julgamos mais pertinentes em todos esses documentos. Nas referências ao final do texto, a lista completa das edições e respectivas páginas do jornal que contém referências ao tema deste artigo.

${ }^{10}$ Documento escrito pela Marinha, Exército e/ou Aeronáutica para seus subordinados.
} 


\section{5-1994: a "Revolução" presente}

Embora oficialmente o Poder Executivo tenha retornado para as mãos de civis com a posse de José Sarney (PMDB) em 15 de março de 1985, o clima foi de grande presença militar na cena política e nas discussões da opinião publicada até, pelo menos, o ano de 1994. No processo de "solução negociada", sobressaiu-se a "constituição de uma tutela militar sobre o governo [Sarney] e a unificação de um campo conservador em seu interior [...] nos marcos da preservação da institucionalidade autoritária." (MACIEL, 2012, p. 60).

Diante de uma conjuntura de inflação descontrolada, planos econômicos fracassados, arrocho salarial, movimento sindical grevista em ascensão e expectativa social quanto à nova Carta Constitucional, o governo Sarney acabou por frustrar as possibilidades de punição dos militares envolvidos em crimes contra os Direitos Humanos na Ditadura. José Sarney vinha de longa história de apoio à Ditadura, sendo inclusive presidente da ARENA e manteve a presença militar no governo (06 ministérios), bem como a Lei de Segurança Nacional, o SNI, e reverteu a tendência de queda nos gastos militares.

Nesse clima de instabilidade política, econômica e social, "os ministros militares advertiam que as Forças Armadas estavam em estado de prontidão e que agiriam se 'um dia a força de nossos argumentos tiver que ser substituída pelos argumentos de nossa força"” (MACIEL, 2012, p. 80). Ou seja, havia a presença militar na política e um espectro de nova intervenção, caso a democracia saísse da "ordem". A Ditadura mantinha-se presente.

No Estadão de 1985, o clima ainda é de ufanismo. Uma pequena matéria comenta a Ordem do Dia das Forças Armadas que, "por determinantes históricas", teve que assumir a direção do Estado e que no "movimento de antanho denominamos 'revolução', concebemo-lo hoje como 'evolução"”, escreveu o ministro da Aeronáutica. Para a Marinha, a "Revolução de 1964" é definida como "um fato histórico, principalmente pela consecução de seu objetivo: a democracia" que estaria consolidada, amadurecida e que "pode a família brasileira vislumbrar o futuro" de paz e harmonia. O ministro do Exército também fala em evolução, elogia a ausência de ruptura na transição e que "o ideário de 64 se eterniza na democracia" $"$. Como se observa, os

\footnotetext{
${ }^{11}$ Jornal O Estado de S. Paulo - 31-03-1985 - p. 10.
} 
militares tentaram criar a memória de que a "revolução de 1964" foi um importante acontecimento que possibilitou a evolução do sistema político brasileiro e que, a partir dali, o país estaria preparado para a democracia. Além disso, não deixaram de, nas entrelinhas, reconhecer que a transição à democracia manteve as estruturas conservadoras.

Em março de 1987, o clima político na Nova República brasileira estava mais agitado e é destaque nas matérias do Estadão: “aeclosão de greves de trabalhadores está preocupando o ministro, "como a todo cidadão brasileiro", bem como "garantiu também que as Forças Armadas 'não vão interferir nas discussões internas da Assembleia Nacional Constituinte". Percebe-se a preocupação militar quanto às greves decorrentes dos fracassados planos econômicos do governo Sarney, bem como os debates sobre a Constituição.

$\mathrm{Na}$ mesma edição, o jornal reproduz trecho da Ordem do Dia conjunta dos militares que diz: "às vésperas de 31 de março de 1964, a nação estava envolta em sombras, perigos e ameaças" e que hoje se vive livremente um novo tempo. Jarbas Passarinho, ex-ministro da Ditadura e então presidente do PDS e senador, mostra a preocupação com a memória ao dizer que "31 de março será julgado quando as paixões não mais interferirem na interpretação da História" e acaba contradito por José Genoíno, deputado do PT e ex-guerrilheiro do Araguaia, para quem denunciar o golpe "é também denunciar esse presente que o repete" ${ }^{\prime 12}$.

$\mathrm{Na}$ edição do dia seguinte, com chamadas de capa, o jornal comprova o tenso clima político. Aspas para o último ex-presidente ditador João Figueiredo, "a grande falha da revolução foi me fazer presidente da República porque fiz esta abertura aí, que pensei que fosse dar numa democracia e deu num troço que eu não sei o que é". Em outra matéria, o ministro da Aeronáutica veio a público negar a existência de um novo golpe militar: "se existe um golpe em marcha [...], ainda não tomei conhecimento" ${ }^{13}$. Na edição de março de 1988, o jornal publica a íntegra da Ordem do Dia da Aeronáutica com elogios à Constituinte na esperança de que "apague os ressentimentos"14.

Em 1989, completou-se 25 anos do golpe civil-militar. Além disso, o país vivia a expectativa para a definição das candidaturas à primeira eleição direta para presidente da República após 29 anos. Embora Fernando Collor já se mostrasse um candidato

\footnotetext{
${ }^{12}$ Jornal O Estado de S. Paulo - 31-03-1987 - p. 02.

${ }^{13}$ Jornal O Estado de S. Paulo - 01-04-1987 - p. 05.

${ }^{14}$ Jornal O Estado de S. Paulo - 31-03-1988 - p. 06.
} 
competitivo, a burguesia brasileira ainda buscava um candidato do campo conservador para fazer frente à pretensa ameaça de esquerda que representavam as candidaturas Lula da Silva e Leonel Brizola ${ }^{15}$ (GUILHERME, 2016).

Na edição de março, o OESP publica que "militares comemoram 25 anos da Revolução". Na matéria, os ministros militares alertam seus subordinados de que o momento atual exigia meditação, atenção e engajamento de todos ao recordar "o fato histórico que foi a Revolução de 1964”, bem como para que não se esqueçam de suas atribuições para a "manutenção da lei e da ordem". Embora a reportagem diga que as comemorações ficarão restritas ao público interno militar, no Rio de Janeiro, o local escolhido foi a antiga sede do DOI-CODI, que gerou protesto do grupo Tortura Nunca Mais ${ }^{16}$.

$\mathrm{Na}$ edição do dia seguinte, há mais referências ao fato. No editorial "O 31 de março completa 25 anos", o OESP, apoiado na Ordem do Dia dos militares, sustenta que apenas as pessoas que não viveram o março de 1964 é que discordam da boa-fé do movimento, pois "a liberdade da democracia estava profundamente ferida [...] vivia-se uma fase preliminar da instalação da República Sindicalista” que beneficiaria Leonel Brizola, sustentado pelos "famosos grupos dos onze em milícia". Importante registrar a crítica que o Estadão faz à Ditadura a partir do governo Costa e Silva, em que se viu "a incompetência dar as mãos ao autoritarismo para decretar a censura que amordaçou a liberdade de expressão e liberou a corrupção para aventuras fantásticas estimuladas pela impunidade" ${ }^{\prime 17}$.

Na mesma edição, o jornal aproveita o aniversário do golpe para comentar sobre a eleição presidencial de 1989. Após "missa em homenagem ao $25^{\circ}$ aniversário da Revolução", os militares presentes protestaram e criticaram o avanço "da esquerda no Brasil e, especificamente" as candidaturas de Brizola e Lula. O general Euclydes Figueiredo, irmão do ex-presidente, disse que "um dos fracassos da Revolução foi não ter afastado definitivamente Leonel Brizola da vida pública [...] continua sendo hoje o mesmo caudilho corrupto e protetor de marginais que foi responsável pelo golpe"18.

\footnotetext{
${ }^{15}$ Lula da Silva foi líder grevista no final dos anos 1970, preso pela Ditadura e, no processo de reabertura política, foi um dos fundadores do PT; Leonel Brizola era cunhado de João Goulart, governador do Rio Grande do Sul e um dos primeiros políticos cassados e exilados da Ditadura. Quando da reabertura política voltou ao Brasil, fundou o PDT e foi governador do Rio de Janeiro.

${ }^{16}$ Jornal O Estado de S. Paulo - 31-03-1989 - p. 05.

${ }^{17}$ Jornal O Estado de S. Paulo - 01-04-1989 - p. 02-03.

${ }^{18}$ Jornal O Estado de S. Paulo - 01-04-1989 - p. 05.
} 
Podemos observar que os militares, embora estivessem oficialmente fora da política há quatro anos, ainda tentavam influenciar no jogo democrático. $\mathrm{O}$ anticomunismo militar da Doutrina de Segurança Nacional da Escola Superior de Guerra (ESG), um dos argumentos oficiais para o Golpe de 1964, continuava forte, mesmo na Nova República. Por "afastar definitivamente" da vida pública um político cassado e obrigado a exilar-se do país por 15 anos, estaria o general sugerindo que Brizola deveria ter tido o mesmo destino trágico que outros "subversivos" presos, torturados e assassinados nos porões da Ditadura?

Fernando Collor de Mello toma posse em 15 de março de 1990 como primeiro presidente eleito pelo voto direto pós-Ditadura e os militares comemoram na Ordem do Dia 31 de março: “o povo escolheu, em eleições livres, o presidente da República [...] a Nação avança no sentido do aperfeiçoamento, cada vez maior, da democracia"19.

No ano de 1991, mais uma vez, a Ordem do Dia dos militares é a base da matéria do Estadão em março. Os militares afirmam no documento que a "Revolução" seria "fato histórico de incontestável importância", mesmo com os erros cometidos. Sem revelar que erros seriam esses, dizia que os militares olham para o passado "sem rancor ou revanchismo, sem o desejo de reabrir feridas". Para justificar a "Revolução", os militares argumentam que no contexto da Guerra Fria, o embate ideológico na sociedade brasileira era entre "a maioria democrática e uma diminuta minoria marxistaleninista, que considera a subversão, o terrorismo e a luta armada", gerou greves, agitações e violência que "agrediram a sociedade" e ameaçaram conduzir o país para o caos. Então, segundo ainda os militares, “o povo respondeu com manifestações cívicas, exigindo o retorno à ordem",20.

Até aqui, esta é a Ordem do Dia mais explícita na tentativa de os militares construírem a memória da opinião pública de que a "Revolução" de 1964 foi uma "contra-revolução" que nasceu do clamor popular contra a ameaça de subversão comunista. Tudo dentro do script ideológico da ESG.

Em 1992, a única referência ao aniversário do golpe é um artigo assinado por Arnaldo Lacombe, editorialista do Estadão. Nele, o articulista argumenta que 1964 foi a complementação do movimento de 1930, que foi desvirtuado por Vargas e Brizola. Sobre os motivos: "não me cabe justificar o Movimento de 31 de março. Os democratas

\footnotetext{
${ }^{19}$ Jornal O Estado de S. Paulo - 31-03-1990 - p. 06.

${ }^{20}$ Jornal O Estado de S. Paulo - 31-03-1991 - p. 07.
} 
sinceros que viveram os dias angustiados do primeiro trimestre daquele ano ainda se lembram de que não era possível não derrubar o governo”.

Com o governo Collor incapaz de resolver o problema da inflação, apesar dos mirabolantes planos econômicos, o perfil personalista do presidente, as complicadas relações com o Parlamento e os crescentes escândalos de corrupção que atingiam a ele, sua família e amigos próximos, em dezembro de 1992, completou-se o processo de impeachmente a efetivação de Itamar Franco na presidência (SALLUM JR, 2015). Forma-se um novo bloco no poder para a implementação da agenda neoliberal iniciada por Collor e a criação do Plano Real (MARTUSCELLI, 2015). Em 1993, uma nota conjunta dos ministros militares pelo "aniversário da revolução democrática de 1964" afirma que o Brasil pré-1964 vivia forte instabilidade e que a "revolução trouxe ao Brasil a harmonia e a tranquilidade”. Ao final, alertam que o momento atual exige reflexão ${ }^{21}$.

Na capa da edição do O Estado de S. Paulo de 31 de março de 1994, entre uma manchete que sugere a "abertura dos setores de petróleo e comunicação" e uma foto de Fernando Henrique Cardoso com uma nota de cem reais e o comentário "nova moeda: agora, a campanha", o jornal apresenta seu caderno especial "30 anos depois...", que avalia as "mudanças radicais que deixaram sequelas em uma geração", os "problemas e virtudes" do "terremoto político de 1964”, cuja herança “está visível nas desigualdades sociais e nos conflitos de interesse" $"$.

No Espaço Aberto da página seguinte, três artigos discutem os 30 anos do golpe. O professor Roberto Macedo, da Universidade de São Paulo e da Universidade Mackenzie, discute os aspectos econômicos pré-1964, da Ditadura e da Nova República. O jornalista Aristóteles Drummond assina texto lambe-botas aos militares, cuja "revolução deixou importante legado de realizações" quando "ocuparam o poder atendendo a reclamos da sociedade" e que, desde 1985, sofre "o revanchismo" da esquerda que demonstra falta de grandeza. Para o jornalista, enquanto as Forças Armada "forem o sustentáculo da sociedade, o poder não cairá nas ruas, a baderna não se instalará, nem a democracia será golpeada pelos radicais" e conclui que "queiram ou não as esquerdas, a Revolução de 64 terá um lugar de destaque na História”. Não é o que escreve Frei Betto, religioso preso na Ditadura, para quem se usa "o eufemismo 'Revolução' para uma típica quartelada imposta no Dia da Mentira e, por isso, recuada

\footnotetext{
${ }^{21}$ Jornal O Estado de S. Paulo - 01-04-1993 - p. 06.

${ }^{22}$ Jornal O Estado de S. Paulo - 31-03-1994 - p. 01.
} 
um dia no calendário oficial” ${ }^{23}$. É a primeira vez que alguém contra a Ditadura escreve no jornal.

Em editorial, "com a autoridade de quem sofreu a censura e teve sua sede atingida duas vezes por petardos criminosos", o Estadão se mostra preocupado em manter viva a "memória dos fatos históricos" contra os antes "grupos terroristas" que hoje estariam posando de "defensores da ordem democrática". Para o jornal, as "reformas de base" de Jango serviriam para implantar "uma República Sindicalista no país" e "reforçar a impressão de que a subversão estava no poder". Porém, a "sociedade se deu conta da iminência dos perigos" e "foi, como se definiu desde os primeiros momentos, uma contra-revolução". O jornal lamenta que "apenas os momentos negros" são lembrados apóso AI- $5^{24}$. No mesmo sentido, o jornal repercute a Ordem do Dia dos ministros militares, que atuaram em 1964 para por fim à ameaça aos "valores básicos da nacionalidade", e rejeita os termos golpe, quartelada ou usurpação do poder ${ }^{25}$.

O caderno extra do Estadão tem ao todo 12 páginas. Na capa, grandes fotos da marcha que comemorou o golpe nas ruas de São Paulo, com pessoas sorridentes e aplaudindo. Segue uma página inteira com a "cronologia da ascensão e queda de Jango", sempre retratado como ameaça esquerdista, e que uma reunião ocorrida em 28 de março teria definido o dia 31 para derrubar o presidente à revelia de Castelo Branco. O jornalista Oliveiros S. Ferreira comenta em texto a experiência de censura que o OESP viveu na Ditadura, "uma luta da qual a Redação saiu vitoriosa". Paulo Francis provoca a reflexão sobre os motivos que levaram Carlos Lacerda e Magalhães Pinto a não se oporem a extensão do mandato de Castelo Branco ${ }^{26}$.

No especial há um denso texto de três páginas assinado pelo político e economista Milton Campos ${ }^{27}$, ex-ministro do Planejamento do governo Castelo Branco $^{28}$, com inúmeros disparates autoritários. Tendo a questão econômica como tema, Campos exalta Castelo como o grande reconstrutor da economia brasileira e culpa os presidentes seguintes e por tabela os economistas que o substituíram, para o

\footnotetext{
${ }^{23}$ Jornal O Estado de S. Paulo - 31-03-1994 - p. 02.

${ }^{24}$ Jornal O Estado de S. Paulo - 31-03-1994 - p.03.

${ }^{25}$ Jornal O Estado de S. Paulo - 31-03-1994 - p.09.

${ }^{26}$ Jornal O Estado de S. Paulo - 31-03-1994 - p.X1, X2 e X3.

${ }^{27}$ Quando da publicação desse texto, Roberto Campos era deputado federal pelo PDS (ex-ARENA) e no mesmo ano foi reeleito pelo PPR (futuro PP) no estado do Rio de Janeiro.

28 Mais informações no link do CPDOC: http://cpdoc.fgv.br/producao/dossies/Jango/biografias/roberto_campos.
} 
esgotamento e crise econômica dos anos 1970-80. Acusa Jango de ter criado uma "aristocracia do proletariado" e que a política salarial de Castelo era mais justa, numa "fórmula de capitalismo democrático". Campos afirma também que "a Constituição de 1967 é uma Constituição democrática, ao contrário do que se diz. Em muito superior à de 1988".

Como parte do contexto de 1994, da pressão do capital internacional pelas privatizações de estatais no Brasil (MARTUSCELLI, 2015), Campos sustenta que na Ditadura houve uma "estatização involuntária" e que "no período Castelo Branco a política era privatista", além disso, o argumento de ser a Petrobrás estratégica "só pode ser uma piada". Campos acusa os demais presidentes de não ter a mesma visão estratégica de Castelo Branco, o que gerou o fracassado intervencionismo na economia, mas que "a única coisa que se pode dizer a favor dos militares é que os civis pioraram muito mais". Na visão do economista, os militares deveriam ter sido neoliberais como Pinochet foi no Chile. Para concluir, Roberto Campos faz uma avaliação de cada presidente militar e lhes atribui notas: Castelo Branco, nota 9; Costa e Silva, nota 3; Médici, nota 7; Geisel, nota 5 e Figueiredo, nota 4. Somamos tudo e dividimos por cinco: a média de 5,6 reprova os militares. Porém, para Campos, "se os militares tivessem continuado, o cenário seria melhor",29.

Se o texto de Roberto Campos escancara a saudade que sente dos tempos autoritários, o mesmo pode ser dito do texto de Armando Falcão, ex-Ministro da Justiça no governo Geisel ${ }^{30}$. Em “será que valeu a pena entregar os pontos?”, Falcão caracteriza 1964 como uma aliança entre o povo e as Forças Armadas, chamando-a de "Revolução democrática, preventiva e defensiva", pois o golpe seria "daqueles outros [...] que ameaçavam destruir a legalidade legítima", em que os militares "souberam dar conta do recado, sem vexame de qualquer natureza" e que os "exaltados" foram uma "fatalidade". Para ele, os que vociferam histericamente o termo "ditadura", que aguardem o "veredito do tempo na voz do povo. Ele será a favor da Revolução. Quem viver verá",31.

Destaco também mais dois textos publicados no Estadão, mas nesse caso, de pessoas que lutaram contra a Ditadura. Importante registrar que, embora haja tal espaço,

\footnotetext{
${ }^{29}$ Jornal O Estado de S. Paulo - 31-03-1994 - p.X4, X5 e X6.

${ }^{30}$ Mais informações no link do CPDOC: http://cpdoc.fgv.br/producao/dossies/JK/biografias/Armando_Falcao.

${ }^{31}$ Jornal O Estado de S. Paulo - 31-03-1994 - p.X7.
} 
ele é consideravelmente menor que o espaço dedicado aos que perfilaram ao lado dos golpistas de 1964. José Genoíno escreve que, em 1964, ocorreu uma "subversão da ordem institucional democrática", que os militares "agiam acima da lei” e desde o início buscaram um discurso que os legitimasse em nome do "combate à subversão, à corrupção". Ante as pressões populares contra a Ditadura, a transição ocorreu por um pacto "entre as elites", sem que houvesse um novo modelo institucional. O antropólogo Darcy Ribeiro, então ministro da Casa Civil de Jango, escreve que, em 1964, o Brasil caminhava para "superar o atraso e acabar com a pobreza", "tudo dentro da democracia e da lei", quando sobreveio o "golpe militar", com ajuda da CIA, que tinha por grande objetivo "impedir a limitação de remessa de lucro e a reforma agrária". Esses dois textos mostram a nítida diferença de interpretação quanto ao golpe de $1964^{32}$.

A sempre polêmica participação estadunidense em 1964 é negada em texto pelo então embaixador dos EUA no Brasil, Lincoln Gordon, para quem o "movimento foi "made in Brazil""33. Também dois historiadores escrevem no especial do Estadão. Thomas Skidmore relembra que o suicídio de Vargas em 1954 adiou por alguns anos a tomada de poder pelos golpistas brasileiros, que "estavam obcecados pelo temor de que o Brasil estivesse escapando ao seu controle", pois "temiam o poder dos trabalhadores organizados". No mesmo sentido, Carlos Mota, da Universidade de São Paulo, aponta o "reacionarismo entranhado" na mentalidade das classes dominantes no pré-1964, que veio reforçar "uma tradição de concentração, exclusão social e criação de uma massa de marginalizados" 34 .

Ainda naquela edição de março de 1994, o OESP, no Caderno Zap!, destinado ao público adolescente, traz os dados de uma interessante pesquisa realizada com 400 estudantes paulistanos de " $1^{\circ}$ e $2^{\circ}$ graus" que responderam a questão: O que aconteceu no dia 31 de março de 1964? Um golpe de Estado no Brasil (39\%); o Brasil ganhou a copa do mundo (19\%); uma revolução no Brasil (15\%); criação da ONU (11\%); foi inventada a penicilina (5\%); não sabe (11\%). O movimento de 1964 foi de Esquerda ou de Direita? Esquerda (61\%); Direita (32\%); não sabe (7\%). Qual presidente foi deposto em 1964? Juscelino Kubitschek (37\%); João Goulart (24\%); Jânio Quadros (22\%); Tancredo Neves (7\%); Café Filho (4\%); não sabe (6\%). Os militares estavam certos ou

\footnotetext{
${ }^{32}$ Jornal O Estado de S. Paulo - 31-03-1994 - p. X8 e X9.

${ }^{33}$ Jornal O Estado de S. Paulo - 31-03-1994 - p. X10 e X11.

${ }^{34}$ Jornal O Estado de S. Paulo - 31-03-1994 - p. X7 e X12.
} 
errados? Errados $(50 \%)$; certos $(43 \%)$; não sabe $(7 \%)^{35}$. Como se observa, há grande confusão entre os estudantes paulistanos em explicar um acontecimento tão recente e importante na história do Brasil.

Podemos perceber que os apoiadores do golpe civil-militar de 1964 têm muito mais espaço nas páginas do Estadão para publicar a versão de que houve uma "revolução democrática com o povo". O jornal atua firmemente na construção de uma memória positiva para a deposição de Goulart, em especial na figura do marechal Castelo Branco e os primeiros anos de governo militar. Além disso, o silêncio sobre as torturas e mortes é perturbador.

\section{5-2004: o "Golpe" distante}

Embalado pelo sucesso que o Plano Real teve em conter a inflação, o sociólogo Fernando Henrique Cardoso (PSDB) é eleito e reeleito presidente da República em primeiro turno, numa aliança política que inclui além de setores do PMDB, o vicepresidente Marco Maciel, do PFL, ex-ARENA. Nos oito anos de poder (1995-2002), FHC consolidou o neoliberalismo no Brasil.

Desde a edição comemorativa dos 30 anos do golpe, em 1994, o Estadão só volta a tratar do assunto no aniversário de 35 anos, na edição de março de 1999. A manchete "Democracia carrega peso dos tempos obscuros criados com o golpe militar" abre um pequeno texto em que se trabalha a tese de alguns analistas de que o “descrédito na política e nos políticos é herança consolidada desde 64" um período “obscuro da história recente do Brasil: a ditadura militar". É a primeira vez que o jornal usa o termo "golpe", além de fazer a clara distinção entre "democracia" e "ditadura". Para o jornal, a Ditadura foi a "grande responsável pela consolidação de uma cultura antidemocrática iniciada por Getúlio Vargas durante o Estado Novo", bem como a "fragilização partidária"36.

Em março de 2000, com chamada de capa, o Estadão segue na defesa da tese de que Castelo Branco teria sido traído em seus ideais democráticos pela "linha dura". Duas reportagens discutem um documento "ultrassecreto" produzido pelos militares em dezembro de 1964 e publicado na íntegra na página seguinte. Na interpretação do jornal, Castelo Branco “enfrentou a pressão da linha dura que tentou obrigá-lo a recorrer à

\footnotetext{
${ }^{35}$ Jornal O Estado de S. Paulo - 31-03-1994 - p. G4.

${ }^{36}$ Jornal O Estado de S. Paulo - 31-03-1999 - p.A06.
} 
tortura, o que acabou ocorrendo nos governos que se sucederam", em especial, os de Costa e Silva e Médici. Além de enfrentar a resistência dos setores à esquerda, Castelo Branco era cobrado pela linha dura para "impor um regime com maior repressão a movimentos políticos e populares" e julgava o governo "pouco ativo em suas medidas repressivas" 37 .

Em março de 2003, já sob o governo do presidente Luis Inácio Lula da Silva (PT), que contava com muitos militantes da luta contra a Ditadura, presos, perseguidos, exilados e até torturados, o Estadão publica que o dia 31 foi "comum nos quartéis, para evitar problemas com o governo do PT", nem mesmo uma Ordem do Dia dos militares foi publicada e lida, ao contrário dos últimos anos. Para a reportagem, o porta-voz do Exército disse que evitar comentários naquela data seria um "exemplo de grandeza" dos militares. O senador Aloísio Mercadante (PT) teria dito ao jornal: "Aniversário da revolução? Não, é aniversário do golpe”, enquanto o presidente Lula, nos três discursos que fez naquele dia, em nenhum momento tocou no tema ${ }^{38}$.

Ao completar-se 40 anos do golpe de 1964, o OESP publica um caderno especial com 20 páginas sobre o aniversário do fato. Em matéria que repercute a Ordem do Dia no Exército, que nenhuma menção faz ao governo petista, o Estadão volta a classificar o fato como "revolução de 1964". Interessante no texto é a informação de que um grupo de militares liderados pelo deputado Jair Bolsonaro (então no PTB) pedem aumentos salariais para a categoria e que o deputado promete comemorar a data de joelhos na Câmara. Aspas para o deputado: "vou agradecer pelo fato de a revolução ter evitado que o Brasil se transformasse numa nova Cuba" ${ }^{\text {"39. }}$.

Ao contrário do especial de 30 anos, dessa vez o Estadão abriu pouco espaço para políticos que participaram daquele evento. A maioria dos textos é de jornalistas. Outro contraste é a capa do especial: se dez anos antes o jornal abria com grandes fotos de pessoas comemorando o golpe, agora a grande foto é de jovens soldados, carrancudos, de armas nas mãos e a frase "40 anos esta noite" 40 . Um texto de três páginas resume os antecedentes do golpe, os principais acontecimentos da Ditadura e o depois na redemocratização.

\footnotetext{
${ }^{37}$ Jornal O Estado de S. Paulo - 31-03-2000 - p. A01, A12 e A13.

${ }^{38}$ Jornal O Estado de S. Paulo - 31-03-2003 - p. A08.

${ }^{39}$ Jornal O Estado de S. Paulo - 31-03-2004 - p. A11.

${ }^{40}$ Jornal O Estado de S. Paulo - 31-03-2004 - p. H1.
} 
Para o jornal, o Brasil estava dividido entre "partidários do imperialismo ianque e os do ouro de Moscou". O senso comum acreditava que Moscou enviava ouro para financiar a luta armada pró-comunista. Aponta o texto que a democracia no país estaria esgotada, com partidos fracos e propícia ao populismo de João Goulart e Juscelino Kubitschek. O jornal admite que "não houve uma revolução: foi um golpe de Estado clássico, do tipo que pontuou a história dos países subdesenvolvidos”. Apesar disso, os fundamentos do golpe pareciam justos à maioria: "o restabelecimento da democracia e a luta contra o comunismo".

O OESP tenta sustentar a tese de que nossa Ditadura foi "híbrida", ao contrário das outras ditaduras do continente, pois sempre buscou legitimidade civil e parlamentar. Contradizendo-se, o jornal resume a história dos Atos Institucionais que cassava, torturava e censurava a população brasileira. Admite o Estadão, que "a eliminação dos canais pacíficos de manifestação empurrou os jovens idealistas para a luta armada" e não o contrário. Trata o texto ainda da OBAN e dos DOI-CODIs, "centrosorganizados de torturas oficial", e que a linha dura pensava eternizar-se no poder. Destaque para a primeira admissão explícita de torturas na Ditadura, inclusive o criminoso caso Vladimir Herzog e o número estimado de 3.500 "exilados, presos, torturados e mortos". O texto segue até a eleição de Tancredo Neves, apontando a campanha pelas Diretas Já como "a mais clara e simbólica vontade do povo"41.

Para o jornal, a Ditadura, graças ao bem-sucedido começo com Castelo Branco, "mudou radicalmente a economia brasileira" com o processo de industrialização do país, complementado nos anos seguintes, apesar das críticas ao intervencionismo econômico. Um gráfico mostra resultados contraditórios: a renda per capta subiu de US\$ 1.060,00 em 1963 para US\$ 2.158,00 em 1984, porém a inflação anual saltou de $81 \%$ para $223 \%$ e a dívida externa passou de 3,6 bilhões de dólares para 102,1 bilhões no mesmo período. Além disso, a distribuição de renda também piorou ${ }^{42}$.

A questão da censura merece duas páginas do especial. O OESP relata desde a apreensão do jornal na gráfica, por conta do editorial "Instituições em Frangalhos" que sairia em 13 de dezembro de 1968, até o fim da presença física do censor na redação, em janeiro de 1975. O Estadão admite que, já no governo Castelo Branco, havia censura a jornais de esquerda, "mas prevaleceu uma relativa liberdade". A censura ao

\footnotetext{
${ }^{41}$ Jornal O Estado de S. Paulo - 31-03-2004 - p. H2, H3 e H4.

${ }^{42}$ Jornal O Estado de S. Paulo - 31-03-2004 - p. H5.
} 
jornal teria deixado inconformado o seu diretor, Júlio de Mesquita Filho, conspirador de primeira hora $^{43}$.

Uma longa e interessante entrevista com Ruy Mesquita, "um dos articuladores do movimento de 1964", nos permite observar bem a posição dos proprietários do Estadão sobre o fato e a disputa pela memória. A família Mesquita teria sido procurada em março de 1964, por dois oficiais do Exército. Segundo o entrevistado, queriam eles "nos articular para enfrentar o golpe que certamente ia ser desferido pelo Jango" e sua casa "era centro da conspiração". No discurso de Mesquita, a articulação seria "um movimento defensivo contra uma ameaça concreta ao regime democrático". Os militares também haviam procurado "outros setores da sociedade" para pedir apoio financeiro para compra de armas no Paraguai. Alegaram que "se cometeram um crime contra a ordem estabelecida" foi em "legítima defesa".

O que o diretor do Estadão diz que pretendia ao participar daquele movimento golpista civil-militar não era uma revolução, mas sim a execução do programa pretensamente defendido pelo marechal Castelo Branco de "limpeza do cenário político, com cassações", mantendo o calendário eleitoral. "Tudo isso seria alterado pelo AI-2", quando o jornal teria rompido com o governo e o "movimento acabou se transformando em 20 anos de ditadura".

Ruy Mesquita sustenta que "a moderação no tratamento dos inimigos da revolução" é que possibilitou a "ousadia" da "esquerda mais radical”, responsável pela decretação do AI-5. O entrevistado tenta “desmistificar” que os Estados Unidos da América tenham participado da conspiração, que Carlos Lacerda fosse um dos conspiradores e que a tortura estivesse institucionalizada. Em conclusão, diz que a Ditadura fez bem ao Brasil, embora a "corrupção grassou nos governos ditatoriais", que o povo brasileiro "aprendeu muito" e só “quem não viveu essa tensão terrível não entende a reação perfeitamente natural dos militares". Porém, aflige-se com o risco de que "a história do golpe de 64 foi escrita pelos derrotados". A consolidação de uma memória positiva parece ter escapado às mãos dos golpistas ${ }^{44}$.

José Serra, presidente da União Nacional dos Estudantes em 1964, conta, em longo texto de estilo vaidoso, os detalhes por ele vividos na conjuntura do golpe. Serra afirma que Jango "não tinha visão estratégica nem gosto" pela política e que ele teria

\footnotetext{
${ }^{43}$ Jornal O Estado de S. Paulo - 31-03-2004 - p. H8.

${ }^{44}$ Jornal O Estado de S. Paulo - 31-03-2004 - p. H9.
} 
tentado aconselhar o presidente em vários momentos ${ }^{45}$. Em outra página inteira, o Estadão trata pela primeira vez, e de forma direta, sobre a tortura e repressão "sangrenta e sem tréguas com os opositores do regime" ditatorial ${ }^{46}$.

Em curta entrevista, o cardeal Paulo Evaristo Arns admite ter apoiado o golpe, mas que rompeu com o movimento a partir da cassação dos ex-presidentes Jânio e JK. Conta Arns, que em suas visitas aos presídios da Ditadura, viu as torturas e passou a denunciá-las, pois "quem aceita isso, não é cristão. Trata-se de um atentado gravíssimo contra a dignidade da pessoa" ${ }^{47}$. A resistência dos grupos de esquerda também é tema do especial, principalmente a atuação de militantes que em 2004 faziam parte do governo petista, como José Genoíno, José Dirceu, Márcio Thomaz Bastos e Eduardo Suplicy. Um box exclusivo é sobre Dilma Vana Rousseff, então ministra de Minas e Energia e sua atuação na POLOP, quando foi presa e torturada por quase três anos ${ }^{48}$.

Destaque maior é para a atuação política de José Sarney, “o equilibrista” e "fundamental para a governabilidade do PT", que tenta se colocar contra o golpe, mas que sempre esteve ao lado dos militares; e Antônio Carlos Magalhães, "ruidoso defensor da queda de Jango" pelo "movimento popular". O especial do Estadão mais uma vez abre espaço para que o embaixador Lincoln Gordon defenda a tese de uma "revolução $100 \%$ brasileira" 49 .

Jarbas Passarinho $^{50}$, golpista em 1964 e que ocupou vários postos de nomeação política durante a Ditadura, ganha espaço no Estadão. Sustenta que não foram as reformas de base que propiciaram a conspiração, mas sim o estímulo dado por Jango à indisciplina militar, e que o AI-5 surgiu como repressão, pois a luta armada "insensata desencadeada pelos comunistas responde pelo período arbitrário necessário às ações militares de defesa do Estado", ou seja, é o clássico discurso de culpar a vítima. Ao final, Passarinho pede que o fato histórico seja analisado sem paixões, para possibilitar a reconciliação nacional, embora afirme que o saldo da Ditadura seja "indesmentivelmente favorável" 51 . Fernando Henrique Cardoso também assina um texto

\footnotetext{
${ }^{45}$ Jornal O Estado de S. Paulo - 31-03-2004 - p. H10 e H11.

46 Jornal O Estado de S. Paulo - 31-03-2004 - p. H12.

${ }^{47}$ Jornal O Estado de S. Paulo - 31-03-2004 - p. H13.

${ }^{48}$ Jornal O Estado de S. Paulo - 31-03-2004 - p. H14 e H15.

49 Jornal O Estado de S. Paulo - 31-03-2004 - p. H16 e H17.

50 Mais informações no link do CPDOC: http://www.fgv.br/cpdoc/acervo/dicionarios/verbetebiografico/jarbas-goncalves-passarinho

${ }^{51}$ Jornal O Estado de S. Paulo - 31-03-2004 - p. H17.
} 
no especial. Para o sociólogo, ex-presidente, "o golpe teve causas acidentais e de conjuntura": Jango fraco politicamente e Congresso sem iniciativa. FHC diz que as acusações de que Jango daria um golpe não tinham "consistência real, mas política também se faz de imagens, símbolos e representações".

Conforme os anos passam e a democracia neoliberal se consolida no país, as referências ao aniversário do golpe de 1964 se escasseiam nas páginas do OESP. Por ocasião dos 40 anos, o jornal dedica mais atenção ao fato, e podemos notar, ao menos, a possibilidade de debate sobre se tivemos "revolução" ou golpe, além de se falar minimamente sobre as torturas e mortes, o que inexistia no período anteriormente analisado.

\section{5-2016: a memória em disputa}

Nas fontes que seguem ao longo dos governos petistas, eleitos e reeleitos, de Lula da Silva e Dilma Rousseff, pretensamente de esquerda, percebemos mais tensões na disputa pela memória sobre o golpe de 1964 e suas consequências, em especial, diante da Comissão de Anistia do Ministério da Justiça ${ }^{52}$ e, principalmente, da Comissão Nacional da Verdade ${ }^{53}$, que buscou investigar violações aos direitos humanos cometidos entre 1946 e 1988. As páginas do Estadão indicam que a disputa pela memória sobre o golpe, a Ditadura, se intensificará na sociedade brasileira durante os governos do PT.

Na edição de abril de 2005, o Estadão publica que o ex-marinheiro, conhecido como Cabo Anselmo, enviou pedido de indenização à "Comissão de Anistia de um governo que inclui muitos esquerdistas traídos por ele", o que teria causado uma "saia justa" aos petistas. Na mesma edição, "Nos 41 anos do golpe, Exército fala em conciliação" é a matéria que trata da Ordem do Dia escrita pelo comandante do Exército, que diz que "os militares escreveram páginas gloriosas da história do Brasil". Por fim, a matéria ainda informa que um grupo de militares da reserva, organizados por Carlos Alberto Ulstra, notório torturador nos tempos da Ditadura, da ONG "Terrorismo Nunca Mais", fincou cruzes de madeira no gramado do Congresso para "lembrar os mortos por grupos de esquerda entre 1964-1985",54.

\footnotetext{
${ }^{52}$ Criada pela Lei 10.559 de 13 de novembro de 2002.

${ }^{53}$ Criada pela Lei 12.528 de 18 de novembro de 2011.

${ }^{54}$ Jornal O Estado de S. Paulo - 01-04-2005 - p. A12.
} 
No ano seguinte, o Estadão repercute a Ordem do Dia do Exército que “orgulha-se do passado", pelo "incontestável apoio popular" para "preservar a democracia". O Exército demonstra preocupação quanto à "imparcialidade" na avaliação sobre os anos da Ditadura que deveria ser feita sem “paixões”. Ressalta ainda que "esse Exército é conciliador sem perder a altivez, generoso com os vencidos, nobre nas atitudes, respeitador da lei, avesso aos ressentimentos". No mesmo dia, o jornal destaca a escolha de Waldir Pires, cassado e ex-exilado político, para o Ministério da Defesa $^{55}$, dizendo que o gabinete, pela primeira vez, "será chefiado por um civil que classifica como 'golpe' o movimento militar de 1964"

No primeiro governo da presidenta Dilma Rousseff, em março de 2012, repercute a cobrança que o Instituto Herzog e a Organização dos Estados Americanos (OEA) fizeram ao relembrar que outros países sul-americanos investem emaveriguações sérias sobre os crimes de suas ditaduras, enquanto que no Brasil, nada ainda "foi investigado para determinar quais foram esses agentes, quais seus nomes, quais seus cargos". Tais entidades cobram a efetiva instalação da Comissão Nacional da Verdade, cujos integrantes ainda não haviam sido nomeados ${ }^{57}$.

Quando dos 50 anos do golpe, O Estado de S. Paulo não publicou mais um dos seus especiais. Apenas um editorial lembra o "movimento civil-militar de 31 de março" que, devido à distância de meio século, possibilita uma "visão mais serena e objetiva" sobre o "desvio do curso original imaginado, em especial, pelas lideranças civis". O Estadão repete a cantilena de que Jango preparava "na marra" as "explosivas" "reformas de cunho socialista, embora não tivesse mandato popular para isso, pois foi eleito vice", o que levou à reação de lideranças civis com o apoio da "maioria da população". O jornal repete o derrotismo com a censura e comemora a redemocratização "de forma pacífica e ordeira"

A luta pela memória é evidente em outra página daquela edição. Uma matéria repercute campanha da Anistia Internacional para recolher assinaturas que visem mudar a Lei de Anistia que "perdoou crimes da ditadura". Ao lado da matéria, uma foto com o bolo que cerca de 150 pessoas fizeram em São Paulo para cantar os parabéns e entoar

\footnotetext{
55 Criado em 1999 em substituição aos extintos Ministério do Exército, Ministério da Marinha e Ministério da Aeronáutica.

${ }^{56}$ Jornal O Estado de S. Paulo - 01-04-2006 - p. A16.

${ }^{57}$ Jornal O Estado de S. Paulo - 01-04-2012 - p. A02 e A11.

${ }^{58}$ Jornal O Estado de S. Paulo - 31-03-2014 - p. A03.
} 
"palavras de ordem em apoio ao ato dos militares em 1964". Na mesma página ainda, o jornal diz que novos documentos confirmam que o ex-presidente João Figueiredo foi avisado um mês antes dos planos de militares em praticarem o atentado ao Riocentro ${ }^{59}$.

$\mathrm{Na}$ edição do dia seguinte, a articulista Dora Kramer classifica como "quartelada" o movimento que, com apoio civil, promoveu o "retrocesso institucional ainda não recuperado". Sobre a polêmica da revisão da Lei de Anistia, o Estadão destaca, em tom comemorativo, que a presidenta Dilma Rousseff teria se posicionado contra, por reconhecer e valorizar "os pactos políticos que nos levaram à redemocratização". A disputa pela memória segue viva: enquanto mil pessoas se reuniram em frente ao DOI-CODI de São Paulo em "homenagem às pessoas torturadas e mortas" e pela revisão da Lei de Anistia, os clubes militares do Rio de Janeiro, "com medo de hostilidade", se reuniram em local fechado para a "comemoração dos 50 anos do golpe", além de reclamar que há "um massacre" ideológico contra a participação militar em 1964 e que a Comissão Nacional da Verdade é "uma afronta à verdade"

Em março de 2016, a disputa pela memória segue nas páginas do OESP. Enquanto o governador Flávio Dino (PCdoB) do Maranhão rebatiza escolas que homenageavam ditadores, como a escola de Timbiras que se chamava Emílio Médici e agora se chama Paulo Freire, um grupo de "organizadores de atos contra Dilma" se uniam para criticar a construção do memorial em homenagem a João Goulart, em Brasília, próximo ao setor militar da cidade. Aspas para um dos organizadores do protesto: "Assim como o Lula convocou o exército vermelho do Stédile, eu convoco o exército glorioso brasileiro para entrar conosco nessa campanha"

Como se percebe, ao longo dos governos petistas, a memória sobre o golpe de 1964 e os anos de Ditadura entrou em evidente processo de disputa ideológica. Nossa hipótese é que a existência de governos pretensamente à esquerda, com vários militantes da luta contra a Ditadura, as seguidas reeleições dos candidatos petistas e a atuação da Comissão Nacional da Verdade propiciaram a reação indignada dos setores conservadores ligados aos civis golpistas e militares, chegando aos ridículos pedidos de "intervenção militar constitucional" contra a "ameaça comunista do PT". As "viúvas de 64 " e os "generais de pijama" rebelaram-se ante o espectro da verdade.

\footnotetext{
${ }^{59}$ Jornal O Estado de S. Paulo - 31-03-2014 - p. A05.

${ }^{60}$ Jornal O Estado de S. Paulo - 01-04-2014 - p. A06.

${ }^{61}$ Jornal O Estado de S. Paulo - 31-03-2015 - p. A06.
} 


\section{Considerações finais}

A análise das fontes acima nos permite perceber que ao longo dos anos pósDitadura, a disputa pela memória do período militar se intensificou nas páginas do Estadão e também na sociedade civil brasileira. O jornal, que nos primeiros anos da Nova República defendia a tese da "revolução popular", passou a amenizar esse discurso ante as novas conjunturas políticas e evidências acadêmicas. No mesmo sentido, o OESP aos poucos abriu espaço para perseguidos políticos publicarem suas interpretações, ainda que em menor número que os espaços reservados aos defensores do período ditatorial. Importante frisar ainda que todos os "especiais" de 30, 40 ou 50 anos do fato foram publicados na data de 31 de março, ou seja, também aqui o Estadão alinha-se à tese dos militares.

O jornalista Carlos Chagas, que trabalhou no O Estado de S. Paulo na quase totalidade dos anos de Ditadura, escreveu recentemente que o jornal da família Mesquita "é o melhor lugar para se trabalhar, quando há ditadura, mas fica apenas conservador quando vem a democracia" (CHAGAS, 2015, p. 14), recolhendo-se às suas contradições ideológicas e políticas. Nos especiais do Estadão, podemos perceber o ressentimento da Família Mesquita, golpistas de primeira hora, com a censura sofrida pelo matutino.

Comparando os três períodos propostos na análise, notamos que nos primeiros anos, a quase totalidade das referências ao golpe e à Ditadura são positivas, de que houve uma "revolução democrática". Os militares continuaram ouvidos e influentes nos desdobramentos da política nacional. No segundo período, as discussões se ampliam, surgem as primeiras críticas e o termo "golpe" é utilizado algumas vezes, mas o movimento é considerado ainda como "contrarrevolução". O último período, sob governos petistas (nos governos tucanos são escassos os debates), a disputa pela memória está mais acirrada e aberta, sendo que em muitos momentos o próprio jornal admite ter sido "golpe". As últimas páginas do matutino nos ajudam a perceber o crescimento de movimentos civis em defesa dos militares e de repulsa à revisão da Lei de Anistia e aos trabalhos da Comissão Nacional da Verdade, cujas complexas razões e desdobramentos ainda estão por ser mais bem pesquisadas, debatidas e compreendidas pela academia ${ }^{62}$.

\footnotetext{
${ }^{62}$ A título de exemplo, indicamos alguns trabalhados que começam a ser publicados no objetivo de analisar a conjuntura do Brasil Contemporâneo: A radiografia do Golpe de Jessé Souza; A forma bruta dos protestos de Eugenio Bucci; e A democracia impedida de Wanderley Guilherme dos Santos.
} 


\section{REFERÊNCIAS}

\section{Fontes primárias}

O Estado de S. Paulo, São Paulo, 03 de abril de 1964, página 01.

O Estado de S. Paulo, São Paulo, 31 de março de 1985, páginas 01 e 10.

O Estado de S. Paulo, São Paulo, 01 de abril de 1986, página 02.

O Estado de S. Paulo, São Paulo, 31 de março de 1987, página 02.

O Estado de S. Paulo, São Paulo, 01 de abril de 1987, páginas 01 e 05.

O Estado de S. Paulo, São Paulo, 31 de março de 1988, páginas 01 e 06.

O Estado de S. Paulo, São Paulo, 31 de março de 1989, página 05.

O Estado de S. Paulo, São Paulo, 01 de abril de 1989, páginas 02, 03, 05.

O Estado de S. Paulo, São Paulo, 31 de março de 1990, página 06.

O Estado de S. Paulo, São Paulo, 31 de março de 1991, página 07.

O Estado de S. Paulo, São Paulo, 31 de março de 1992, página 11.

O Estado de S. Paulo, São Paulo, 01 de abril de 1992, página 02.

O Estado de S. Paulo, São Paulo, 01 de abril de 1993, página 06.

O Estado de S. Paulo, São Paulo, 31 de março de 1994, páginas A1, A2, A3, A9, G1, G2, G4, X1 a X12.

O Estado de S. Paulo, São Paulo, 01 de abril de 1994, página A2.

O Estado de S. Paulo, São Paulo, 31 de março de 1999, página A6.

O Estado de S. Paulo, São Paulo, 31 de março de 2000, páginas A1, A12, A13.

O Estado de S. Paulo, São Paulo, 01 de abril de 2003, página A8.

O Estado de S. Paulo, São Paulo, 31 de março de 2004, página A1, A11, H1 a H20.

O Estado de S. Paulo, São Paulo, 01 de abril de 2004, página A8.

O Estado de S. Paulo, São Paulo, 01 de abril de 2005, página A12.

O Estado de S. Paulo, São Paulo, 01 de abril de 2006, página A16.

O Estado de S. Paulo, São Paulo, 01 de abril de 2007, página A12, A13. 
O Estado de S. Paulo, São Paulo, 31 de março de 2012, páginas A2, A11.

O Estado de S. Paulo, São Paulo, 31 de março de 2013, página A9.

O Estado de S. Paulo, São Paulo, 31 de março de 2014, páginas A3, A5.

O Estado de S. Paulo, São Paulo, 01 de abril de 2014, páginas A1, A6.

O Estado de S. Paulo, São Paulo, 31 de março de 2015, página A6.

\section{Fontes secundárias}

AQUINO, Maria Aparecida de. Censura, Imprensa e Estado autoritário (19681978): o exercício cotidiano da dominação e da resistência - O Estado de São Paulo e Movimento. Bauru: Edusc, 1999.

BECKER, Jean-Jacques. A opinião pública. In: RÉMOND, René (Org.).Por uma história política. Rio de Janeiro: editora FGV, 2003.

CAPELATO, Maria Helena. História do Tempo Presente: a grande imprensa como fonte e objeto de estudo. In: DELGADO, Lucilia de Almeida Neves; FERREIRA, Marieta de Moraes (Org.). História do Tempo Presente. Rio de Janeiro: editora FGV, 2014.

CARDOSO, Ciro Flamarion; VAINFAS, Ronaldo. História e análise de texto. In: CARDOSO, Ciro Flamarion; VAINFAS, Ronaldo (Org.). Domínios da História. Rio de Janeiro: Elsevier, 1997.

CHAGAS, Carlos. A ditadura militar e a longa noite dos generais (1970-1985). Rio de Janeiro: Record, 2015.

CHAGAS, Carlos. A ditadura militar e os golpes dentro do golpe (1964-1969). Rio de Janeiro: Record, 2014.

CHARAUDEU, Patrick. Discurso das mídias. São Paulo: Contexto, 2013.

FICO, Carlos. História do Brasil Contemporâneo: da morte de Vargas aos dias atuais. São Paulo: Contexto, 2015.

GUILHERME, Cássio Augusto. A eleição de 1989: direita x esquerda. Revista Urutágua, Maringá, n. 34, p. 87-109, nov. 2016. Disponível em: <http://www.periodicos.uem.br/ojs/index.php/Urutagua/article/view/34133/17933>. Acesso em: 08 dez. 2016.

HERNANDES, Nilton. A mídia e seus truques. São Paulo: Contexto, 2012.

LUCA, Tânia Regina de. História dos, nos e por meio dos periódicos. In: PINSKY, Carla (Org.). Fontes Históricas. São Paulo: Contexto, 2011. 
MACIEL, David. De Sarney a Collor: reformas políticas, democratização e crise (1985-1990). São Paulo: Alameda, 2012.

MARTUSCELLI, Danilo Enrico. Crises políticas e capitalismo neoliberal no Brasil. Curitiba: CRV, 2015.

SALLUM JR, Brasílio. O impeachment de Fernando Collor: sociologia de uma crise. São Paulo: Editora 34, 2015.

SILVA, Carla Luciana. Imprensa liberal, imprensa partidária: uma aproximação historiográfica. In: SILVA, Carla Luciana; RAUTENBERG, Edina (Org.). História e imprensa: estudos de hegemonia. Porto Alegre: FCM editora, 2014.

SILVA, Carla Luciana; RAUTENBERG, Edina (Org.). História e imprensa: estudos de hegemonia. Porto Alegre: FCM editora, 2014.

SILVA, Juremir Machado da. 1964 - Golpe midiático-civil-militar. Porto Alegre: Sulina, 2014. 